\title{
Synthesis of the Exosporium During Sporulation of Bacillus cereus
}

\author{
By JOHN P. DESROSIER*† AND J. CANO LARA \\ Department of Microbiology and Immunology, University of Washington, Seattle, \\ Washington 98195, USA
}

(Received 13 May 1983; revised 22 November 1983)

Techniques of antigenic analysis were used to examine the synthesis of the exosporium during sporulation of Bacillus cereus. An antiserum to a soluble extract of exosporium from mature spores was used to analyse extracts of cells from various stages of the Bacillus life cycle by the technique of one-dimensional immunoelectrophoresis. Exosporium antigens were absent from vegetative cell extracts and were first detected in extracts of cells at stage III of sporulation, where they appeared simultaneously in the soluble and particulate cellular fractions. The results indicate that the exosporium contains antigens which are spore specific.

\section{INTRODUCTION}

The exosporium is the outermost integument of certain bacterial endospores. That of Bacillus cereus is a large balloon-like structure which is not attached to the rest of the spore. Although the exosporium is the most prominent structure surrounding the B. cereus spore, it has not been as extensively characterized as the other integument structures. Matz et al. (1970) reported that isolated exosporium from $B$. cereus $\mathrm{T}$ is composed primarily of protein with carbohydrate and lipid also present. High resolution electron microscopy has shown that the exosporium consists of a paracrystalline basal layer and a hair-like outer layer (Gerhardt \& Ribi, 1964; Lund et al., 1978).

Compared with other integument structures, little is known about the synthesis of the exosporium. While there are several studies which detail the synthesis of the spore coat proteins (Aronson \& Horn, 1969; Munoz et al., 1978; Nakayama et al., 1978; Uchida et al., 1976), investigation of exosporium synthesis has been restricted to electron microscopy. It has been shown, using immunocytochemical methods, that exosporium antigens are localized within the mother cell compartment during sporulation and are not found in cells before septation (Short \& Walker, 1975; Short et al., 1977). Ohye \& Murrell (1973) have shown that exosporium development begins during stage IV of sporulation at one pole of the forespore. Further exosporium material is added to this initial locus until the structure is completed.

The aim of the present study was to examine the synthesis of the exosporium during sporulation in $B$. cereus. We removed, isolated and solubilized the exosporium and made an antiserum to its soluble extract. The antiserum was used in one-dimensional immunoelectrophoresis to probe extracts of cells from various stages of the sporulation cycle for the presence of cross-reacting material. The results indicate that exosporium antigens are specific to sporulating cells and first appear at stage III of sporulation.

\section{METHODS}

Bacterium and media. Bacillus cereus 9373 was grown in $\mathrm{G}$ medium under conditions previously described (DesRosier \& Lara, 1981).

Isolation of exosporium. The exosporium was removed from spores of $B$. cereus and isolated by a modification of

† Present address: Department of Biology, Middlebury College, Middlebury, Vermont 05753, USA.

Abbreviation: DTE, dithioerythritol. 
the technique developed by Gerhardt \& Ribi (1964). In a typical experiment, washed spores from 10 litres of culture were resuspended in $100 \mathrm{ml}$ distilled water and subjected to hydrostatic pressure treatment in a French pressure cell (American Instruments, Silver Spring, Md., USA) operated at $32000 \mathrm{lbf} \mathrm{in}^{-2}$ (221 MPa). Exosporium fragments were separated from the spores by differential centrifugation at $4500 \mathrm{~g}$. The supernatant fluid was saved, and the pellet was resuspended in $100 \mathrm{ml}$ distilled water and subjected to a second pressure cell treatment. After a second differential centrifugation, the supernatant fluids were pooled and a final centrifugation was done at $3500 \mathrm{~g}$. The resulting supernatant fraction, enriched with exosporium fragments, was concentrated to approximately $10 \mathrm{ml}$ in.an Amicon filtration apparatus (Amicon, Lexington, Mass., USA) using a PM-10 filter. To remove contaminating spores further, the sample was subjected to equilibrium density centrifugation on six $11 \mathrm{ml}$, preformed, $45-70 \%(\mathrm{w} / \mathrm{v})$ renografin- 76 (Squibb) gradients at $68000 \mathrm{~g}$ at $4{ }^{\circ} \mathrm{C}$ for $3 \mathrm{~h}$. After centrifugation, two bands were observed, one enriched with spores and the other with exosporium fragments. The gradients were fractionated from the bottom, and the fractions containing exosporium were pooled and dialysed against distilled water at $4{ }^{\circ} \mathrm{C}$. After dialysis and another banding in renografin, the exosporium fragments were sedimented at $36000 \mathrm{~g}$ at $4{ }^{\circ} \mathrm{C}$ for $1 \mathrm{~h}$. The resulting pellet was translucent, and upon resuspension in $5 \mathrm{ml}$ distilled water contained approximately one spore per five fields of view at $800 \times$ magnification under the phase contrast microscope.

Exosporium solubilization. The exosporium was solubilized in $0.05 \mathrm{M}$-dithioerythritol (DTE) and $1 \%$ (w/v) SDS

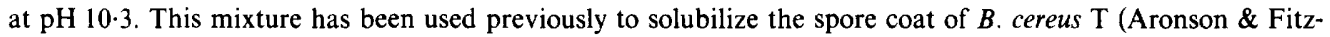
James, 1968). Isolated exosporium fragments were resuspended in alkaline DTE/SDS and incubated on a shaker at $37^{\circ} \mathrm{C}$ for $90 \mathrm{~min}$. The mixture was centrifuged at $36000 \mathrm{~g}$ at $20^{\circ} \mathrm{C}$ for $1 \mathrm{~h}$ and the supernatant dialysed against distilled water at room temperature for $20 \mathrm{~h}$. Approximately $900 \mu \mathrm{g}$ extracted exosporium protein $(80 \%$ of the total) per litre of original culture was obtained by this method. Extracts were stored at $-20^{\circ} \mathrm{C}$.

Preparation of antiserum. Exosporium antiserum was prepared by methods described previously (DesRosier \& Lara, 1981). Rabbits were immunized with a soluble exosporium extract containing $100 \mu \mathrm{g}$ protein per injection. The immunoglobulin $G$ fraction of the serum was obtained by standard methods (Harboe \& Ingild, 1973) and stored at $-20^{\circ} \mathrm{C}$.

Preparation of vegetative and sporulating cell extracts. Cultures of $B$. cereus were synchronized for sporulation using the serial transfer technique of Church \& Halvorson (1957). Cells were inoculated into $50 \mathrm{ml} \mathrm{G}$ medium in a $250 \mathrm{ml}$ Erlenmeyer flask and grown with vigorous aeration at $30.5^{\circ} \mathrm{C}$ on a rotary shaker. When the culture reached an approximate $\mathrm{OD}_{600}$ of $0.8,1.0 \mathrm{ml}$ was transferred into $50 \mathrm{ml}$ prewarmed $\mathrm{G}$ medium in a $250 \mathrm{ml}$ flask. Two more identical transfers were done at the same intervals. A fourth transfer of $6 \mathrm{ml}$ into $300 \mathrm{ml}$ in a 2 litre flask was again allowed to grow to an $\mathrm{OD}_{600}$ of 0.8 at which time the entire culture was poured aseptically into a 12 litre New Brunswick microferm at $30.5{ }^{\circ} \mathrm{C}$. The culture was agitated at 150 r.p.m. and aerated at a rate of 6 litres $\mathrm{min}^{-1}$. Samples of 400 to $600 \mathrm{ml}$ were removed during vegetative growth and at 45 to $60 \mathrm{~min}$ intervals during sporulation. After removal of $70 \mathrm{ml}$ of each sample for electron microscopy, the remaining cell sample was pelleted, washed in $0.2 \mathrm{M}$-potassium phosphate buffer, $\mathrm{pH} 7 \cdot 4$, and stored at $-20^{\circ} \mathrm{C}$.

The frozen pellets were thawed as needed and resuspended in 3 to $5 \mathrm{ml} \mathrm{T}$ buffer $(20 \mathrm{~mm}$ - Tris/ $\mathrm{HCl}, 10 \mathrm{mM}$ $\mathrm{MgCl}_{2}, 10 \mathrm{mM}-\mathrm{CaCl}_{2}$ ) containing the protease inhibitors phenylmethylsulphonyl fluoride and $o$-phenanthroline at a concentration of $1 \mathrm{~mm}$. Cell breakage, accomplished by two passages through a French pressure cell at $28000 \mathrm{lbf} \mathrm{in}^{-2}$ was estimated to be greater than $95 \%$ under the phase contrast microscope. DNAase I was added to the lysate to give a final concentration of $1 \mathrm{mg} \mathrm{ml}^{-1}$ and the mixture was incubated at $25^{\circ} \mathrm{C}$ for $5 \mathrm{~min}$. Particulate matter was removed by centrifugation at $36000 \mathrm{~g}$ at $4{ }^{\circ} \mathrm{C}$ for $60 \mathrm{~min}$. The supernatant, designated as the soluble cell fraction, was carefully removed and stored at $-4{ }^{\circ} \mathrm{C}$. The pellet was resuspended in 1.0 to $2.5 \mathrm{ml}$ of DTE/SDS, $\mathrm{pH} 10 \cdot 3$, and incubated at $37^{\circ} \mathrm{C}$ for $90 \mathrm{~min}$ on a shaker. Insoluble material was spun down at $36000 \mathrm{~g}$ and the supernatant was carefully removed. The extract was dialysed at room temperature against $\mathrm{T}$ buffer for $24 \mathrm{~h}$ and stored at $-4{ }^{\circ} \mathrm{C}$. The extract was designated as being from the particulate cell fraction.

Protein determinations. Protein was estimated by the Lowry method, with bovine serum albumin as standard.

Immunoelectrophoresis. This was done according to the general method of Weeke (1973a) using glass microscope slides for support. Washed slides were coated with a thin layer of $2 \%$ agarose (aqueous, Seakem ME, FMC Corp., Rockland, ME, USA) 'glue', dried at $60{ }^{\circ} \mathrm{C}$ and stored for later use. Immediately before electrophoresis, slides were covered with $0.5 \%$ agarose (in barbital buffer, $\mathrm{pH} 8.6,0.01$ ionic strength) at $55^{\circ} \mathrm{C}$ containing $0.5 \%(\mathrm{v} / \mathrm{v})$ Triton X-100 and $0.05 \%(\mathrm{w} / \mathrm{v})$ sodium deoxycholate. To every $625 \mathrm{~mm}^{2}$ of slide area was added $1.0 \mathrm{ml}$ of this agarose solution to give a gel approximately $1.6 \mathrm{~mm}$ deep. The antibody-containing portion of the gel was made by cutting out the middle section of agarose and replacing it with an agarose/antiserum mixture at $55^{\circ} \mathrm{C}$. Antigen wells of $10 \mu \mathrm{l}$ were cut with a $3 \mathrm{~mm}$ inner diameter hollow metal tube. The electrophoresis running buffer was barbital buffer at $\mathrm{pH} 8.6$ and 0.02 ionic strength. Five sheets of Whatman no. 1 filter paper cut to the exact width of the slide were used as wicks.

One-dimensional or rocket immunoelectrophoresis was done on $50 \times 75 \mathrm{~mm}$ glass slides with one-half of the slide area containing antiserum (Weeke, 1973b). Electrophoresis was done at $4 \mathrm{~V} \mathrm{~cm}^{-1}$ for $3 \mathrm{~h}$. Two-dimensional or crossed immunoelectrophoresis was done on $37 \times 75 \mathrm{~mm}$ slides. A single antigen well was cut in the bottom left- 


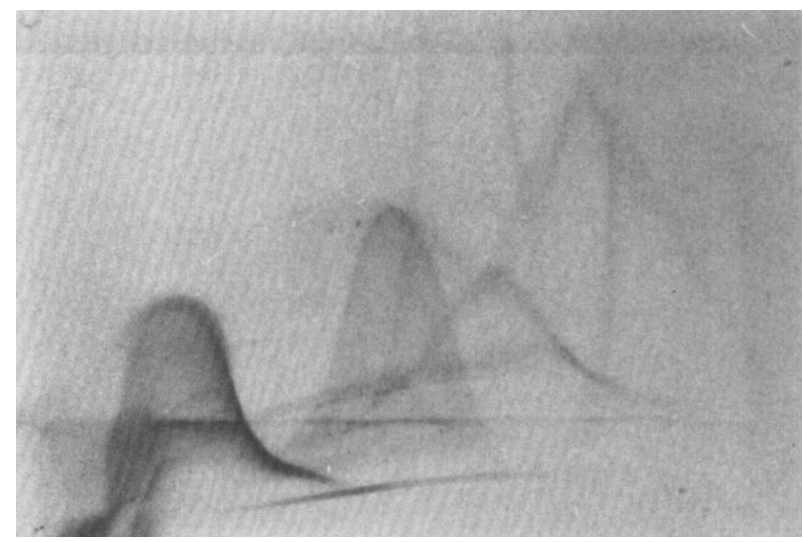

Fig. 1. Characterization of antiserum to the B. cereus exosporium by two-dimensional immunoelectrophoresis. The antiserum concentration was $2.5 \%(\mathrm{v} / \mathrm{v}), 0.98 \mathrm{mg}$ protein. The antigen was $12 \mu \mathrm{g}$ of DTE/SDS-soluble exosporium protein.

hand corner of the agarose gel and electrophoresis was done in the first dimension at $4 \mathrm{~V} \mathrm{~cm}^{-1}$ for $90 \mathrm{~min}$. The upper two-thirds of the gel was subsequently removed and replaced with agarose-containing antiserum. Electrophoresis was done in a direction at right angles to that of the first dimension at $2 \mathrm{~V} \mathrm{~cm}^{-1}$ for $8 \mathrm{~h}$ (Weeke, 1973c). All immunoelectrophoresis experiments were repeated several times; the data shown are representative.

\section{RESULTS}

The exosporium antiserum was characterized for reactivity against a DTE/SDS extract of the exosporium by crossed immunoelectrophoresis (Fig. 1). Several different precipitin peaks were present, indicating that the antiserum contained antibodies to a variety of different exosporium antigens. The presence of horizontal precipitin lines suggested that aggregation may have occurred in the exosporium extract. Aggregation may have arisen as it was necessary to remove the solubilizing agents (DTE and SDS) before electrophoresis to facilitate antigen-antibody interaction. Pre-immune serum was found to be non-reactive with the exosporium extract.

The antiserum was subsequently used to examine cell extracts from a synchronized culture of $B$. cereus for the presence of cross-reacting material. Ten samples were taken which encompassed both exponential phase cells and cells at representative stages of sporulation. The first two samples were at mid and late exponential phases of growth, respectively. Examination of thin sections showed that cells in the fifth sample were at stage III (forespore engulfment), and those in sample ten were at stage VI (maturation). Synchrony was estimated by electron microscopy to be approximately $90 \%$.

The cell extracts were tested for cross-reaction with the exosporium antiserum by rocket immunoelectrophoresis. Each series of ten soluble and particulate cell extracts was run on a single slide and a DTE/SDS extract of isolated exosporium was included as a reference. In both the soluble (Fig. $2 a$ ) and the particulate (Fig. $2 b$ ) extracts immunoprecipitates first appeared at stage III. In the soluble extract, the precipitate formed close to the antigen well, while in the particulate extract the precipitate formed further into the gel. In the particulate extract series, immunoprecipitates increased in size and the precipitation pattern became more complex with later samples. In the soluble extract series, the immunoprecipitate complexity again increased as sporulation proceeded. The precipitation pattern from both the soluble and particulate fractions of the tenth sample was qualitatively similar to that of the exosporium reference.

These results indicate that exosporium antigens are absent from vegetative cells and first appear during the engulfment stage of sporulation. This conclusion, however, is dependent upon the sensitivity of the antiserum, which was also tested by rocket immunoelectrophoresis. Serial dilutions of a DTE/SDS exosporium extract were tested for their ability to form immunoprecipitates with the serum. As little as $6 \mathrm{ng}$ protein was detectable as a precipitate (data not 
(a)

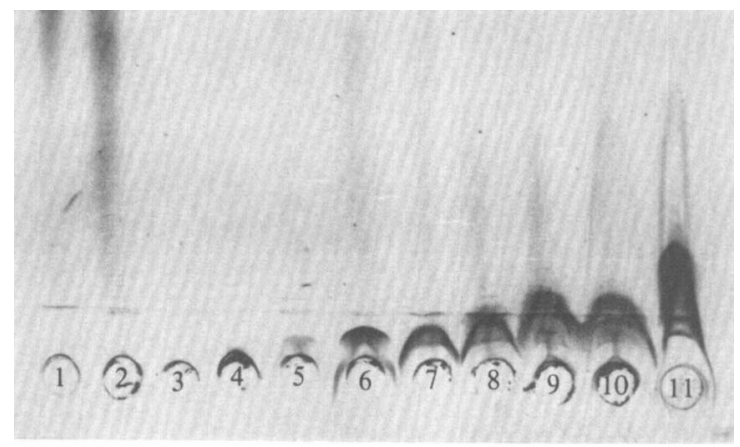

(b)

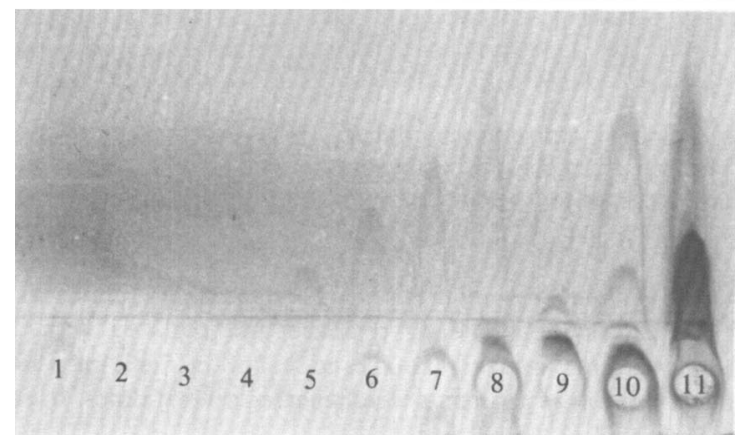

Fig. 2. Rocket immunoelectrophoresis of extracts of B. cereus cells at various stages in the sporulation cycle using exosporium antiserum at a concentration of $5 \%(\mathrm{v} / \mathrm{v}), 1.95 \mathrm{mg}$ protein. Wells 1 to 10 represent stages from vegetative cells to cells in stage VI of sporulation. Well 11 contains a DTE/SDS exosporium extract for reference. (a) Extracts from the soluble cell fraction. The amount of protein per well ( $\mu \mathrm{g})$ was: (1) 100 , (2) 200, (3) 120, (4) 163, (5) 139, (6) 167, (7) 160, (8) 176, (9) 163, (10) 141, (11) 4.8. (b) Extracts from the particulate cell fraction. The amount of protein per well $(\mu \mathrm{g})$ was: (1) $5 \cdot 4$, (2) $7 \cdot 4$, (3) 20, (4) 44, (5) 28, (6) 23, (7) 7, (8) 5 , (9) 5 , (10) 10, (11) 4.8 .

shown) whereas no precipitates were formed when either exosporium protein or antiserum alone were subjected to electrophoresis. From these limits of detectability it appeared that the number of molecules of a particular antigen of molecular weight 50000 that must be present in an individual cell to be detected by immunoelectrophoresis is 35 to 170 . The range was representative of the sample assayed and applied whether the extract was from the soluble or particulate fraction of the cell.

\section{DISCUSSION}

The exosporium from the spores of $B$. cereus is biochemically complex (Matz et al., 1970). In the present study, the several immunoprecipitation peaks seen when soluble extracts of the exosporium were run against an exosporium antiserum in crossed and rocket immunoelectrophoresis indicate that many different antigenic species are components of this structure. This would agree with the data of Beaman et al. (1971), who resolved a variety of different polypeptides from the exosporium of $B$. cereus $T$ on polyacrylamide gels. When extracts from sporulating cells were probed for exosporium antigens by rocket immunoelectrophoresis, the patterns of immunoprecipitation became increasingly complex as sporulation proceeded. This suggests that different antigens contained within the exosporium accumulate at different rates. Because the exosporium is found on spores but not on vegetative or sporulating cells, it may be expected that its constituent macromolecules would be synthesized only during the process of sporulation. The immunoelectrophoretic data from the present study indicate that exosporium antigens are indeed restricted to sporulating cells. These antigens first appeared during stage III and may consequently be considered spore specific. The appearance of exosporium antigens at 
the time of forespore engulfment indicates that exosporium synthesis is an 'early' sporulation event. These results agree with those of Short \& Walker (1975) and Short et al. (1977), who used antisera against whole spores and isolated exosporia to localize exosporium antigens immunocytochemically in thin sections of $B$. cereus. By this method no exosporium antigens were detected in vegetative cells or in cells before the septation stage of sporulation, whereas they were found in cells undergoing engulfment and in stages thereafter. Our data also agree with the observations of Scherrer \& Sommerville (1977), who have suggested that the B. thuringiensis exosporium is synthesized during stages II and III. Similarly, the start of synthesis of other integument-related proteins during stages II and III has been reported, e.g. those which comprise the spore coat of $B$. cereus T (Aronson \& Horn, 1969) and Clostridium perfringens (Labbe \& Duncan, 1977) and the parasporal crystal of B. thuringiensis (Aronson \& Fitz-James, 1976; Somerville, 1971).

Correlation of exosporium synthesis with forespore engulfment seems fitting in that it is during the stage immediately following that the beginnings of exosporium deposition can be detected cytologically (Ohye \& Murrell, 1973). Thus, the simultaneous appearance of crossreacting material in both the soluble and particulate fractions of the cell could indicate that exosporium antigens begin to assemble soon after they have been synthesized. However, exosporium antigens might also appear in the particulate fraction without having assembled if, as Ohye \& Murrell (1973) have suggested, exosporium synthesis is intimately associated with the forespore membranes.

J. P. D. was supported during this period by a National Science Foundation Graduate Fellowship.

\section{REFERENCES}

Aronson, A. I. \& Fitz-James, P. C. (1968). Biosynthesis of bacterial spore coats. Journal of Molecular Biology 33, 199-212.

Aronson, A. I. \& Fitz-James, P. C. (1976). Structure and morphogenesis of the bacterial spore coat. Bacteriological Reviews 40, 360-402.

Aronson, A. I. \& HoRN, D. (1969). Synthesis and regulation of the bacterial spore coat. In Spores $I V$, pp. 72-81. Edited by L. L. Campbell. Bethesda: American Society for Microbiology.

Beaman, T. C., Pankratz, H. S. \& Gerhardt, P. (1971). Paracrystalline sheets reaggregated from solubilized exosporium of Bacillus cereus. Journal of Bacteriology 107, 320-324.

Church, B. D. \& Halvorson, H. O. (1957). Intermediate metabolism of aerobic spores. I. Activation of glucose oxidation in spores of Bacillus cereus var. terminalis. Journal of Bacteriology 73, 470-476.

DesRosier, J. P. \& LARA, J. C. (1981). Isolation and properties of pili from spores of Bacillus cereus. Journal of Bacteriology 145, 613-619.

GERHARDT, P. \& RIBI, E. (1964). Ultrastructure of the exosporium enveloping spores of Bacillus cereus. Journal of Bacteriology 88, 1774-1789.

HARBOE, N. \& INGILD, A. (1973). Immunization, isolation of immunoglobulins, estimation of antibody titer. In $A$ Manual of Quantitative Immunoelectrophoresis, pp. 161-164. Edited by N. H. Axelson, J. Kroll \& B. Weeke. Oslo: Universitetsforlaget.

Labbe, R. G. \& Duncan, C. L. (1977). Spore coat protein and enterotoxin synthesis in Clostridium perfringens. Journal of Bacteriology 131, 713-715.

Lund, B. M., Gee, J. M., King, N. R., Horne, R. W. \& HARNDEN, J. M. (1978). The structure of the exosporium of a pigmented Clostridium. Journal of General Microbiology 105, 165-174.

Matz, L. L., Beaman, T. C. \& Gerhardt, P. (1970). Chemical composition of exosporium from spores of Bacillus cereus. Journal of Bacteriology 101, 196-201.

Munoz, L. E., Nakayama, T. \& DoI, R. H. (1978). Expression of spore coat protein gene, an 'early sporulation gene', and its relationship to RNA polymerase modification. In Spores VII, pp. 213219. Edited by G. Chambliss \& J. C. Vary. Washington, DC: American Society for Microbiology.

Nakayama, T., Munoz, L. E., Sadaie, Y. \& Doi, R. H. (1978). Spore coat synthesis in cell-free systems from sporulating cells of Bacillus subtilis. Journal of Bacteriology 135, 952-960.

Ohye, D. F. \& Murrell, W. G. (1973). Exosporium and spore coat formation in Bacillus cereus $\mathrm{T}$. Journal of Bacteriology 115, 1179-1190.

SCherRer, P. S. \& Somerville, H. J. (1977). Membrane fractions from the outer layers of spores of Bacillus thuringiensis with toxicity to lepidopterous larvae. European Journal of Biochemistry 72, 479-490.

ShorT, J. A. \& WALKER, P. D. (1975). The location of bacterial antigens on sections of Bacillus cereus by use of the soluble peroxidase-anti-peroxidase complex and unlabelled antibody. Journal of General Microbiology 89, 93-101.

Short, J. A., Walker, P. D., Hine, P. \& Thomson, R. O. (1977). Immunocytochemical localization of spore specific antigens in ultrathin sections. Journal of Applied Bacteriology 43, 75-82.

Somer VILLE, H. J. (1971). Formation of the parasporal inclusion of Bacillus thuringiensis. European Journal of Biochemistry 18, 226-237. 
Uchida, A., Kadota, H. \& Schaeffer, P. (1976). Appearance of spore coat protein in the cell extracts of Bacillus subtilis asporogenic mutants. Journal of Bacteriology 126, 1242-1343.

WEEKE, B. (1973a). General remarks on principles, equipment, reagents and procedures. In $\boldsymbol{A}$ Manual of Quantitative Immunoelectrophoresis, pp. 15-35. Edited by N. H. Axelson, J. Kroll \& B. Weeke. Oslo: Universitetsforlaget.
WeEKE, B. (1973b). Rocket immunoelectrophoresis. In A Manual of Quantitative Immunoelectrophoresis, pp. 37-46. Edited by N. H. Axelson, J. Kroll \& B. Weeke. Oslo: Universitetsforlaget.

WEEKE, B. $(1973 c)$. Crossed immunoelectrophoresis. In A Manual of Quantitative Immunoelectrophoresis, pp. 47-56. Edited by N. H. Axelson, J. Kroll \& B. Weeke. Oslo: Universitetsforlaget. 